(C) Springer Nature Switzerland AG 2018

Encyclopedia of Global Archaeology

10.1007/978-3-319-51726-1_2660-1

\title{
Jacquetta Hawkes
}

Christine Finn ${ }^{1}$

(1)Flinders University, Adelaide, Australia

Christine Finn

Email: christine.finn@gmail.com

\section{Basic Biographical Information}

Jessie Jacquetta Hawkes (nee Hopkins) also known as Jacquetta Priestley was born on August 5, 1910, in Cambridge, UK. Her father was the Nobel prize-winning biochemist and Trinity don, Frederick Gowland Hopkins, and her mother, Jessie Ann, introduced her to museums. After an early declaration that she wanted to be an archaeologist, in 1929 she was one of the first to read for the new Cambridge degree of archaeology and anthropology. She left Newnham College with a first-class degree and an invitation to dig with Dorothy Garrod at Mount Carmel in Palestine. Her experience there, exposing a Neanderthal skeleton, had a marked effect on her, and she returned to this discovery in her prose and poetry. By then she had met another promising archaeologist, Christopher Hawkes, both working on a Roman site near Colchester. In 1933 they married and began what appeared to be a union of mutual interests, with a home in North London. Their only child, Nicolas, was born in 1937, and their first book together, Prehistoric Britain, was published in 1943. By then Jacquetta had taken over the second volume of The Archaeology of the Channel Islands from her husband's British Museum colleague, Tom Kendrick. This 1938 monograph helped her academic recognition, and she was elected a Fellow of the Society of Antiquaries. Prehistoric Britain already evidenced the different ways Jacquetta approached the past. Her contribution is the more lyrical, a style which would define her as a poet as much as an archaeologist, most notably in the 1951 book, $A$ Land. By the time of its publication, to excellent reviews from literary critics, Jacquetta and Christopher's troubled marriage was ending.

It was significant that Jacquetta Hawkes remained in London during WW2; Christopher was awarded the Chair of Prehistory at Oxford, but his wife did not move there with him. She remained in London and worked for the civil service, notably the Ministry for Education, where her role was broad and public and enabled her to share her love of archaeology widely. She scripted a film, "The Beginning of History" (1946), and began to be published as a poet, encouraged by the Australian poet and critic, Walter Turner, with whom she had an affair. Central to Britain's postwar culture, she widened her circle beyond traditional archaeology to include artists, philosophers, photographers, and poets. In 1943 she was made principal and secretary of the UK commission for a new cultural body, UNESCO. At a conference in Mexico City in 1947, she began an affair with the celebrated writer, JB or Jack Priestley. After two much publicized divorces, the couple were married in July 1953. During their life together - Priestley died in 1984 - Jacquetta Hawkes continued to introduce 
her beloved archaeology to as wide an audience as possible, including children, lectured widely, and was a regular contributor to $\mathrm{BBC}$ radio and television.

She coedited UNESCO's prehistory volume against a background of new scientific data and, in 1968, in a widely debated Antiquity paper, warned that archaeology risked being narrowed by scientific development. She was encouraged to write the biography of Sir Mortimer Wheeler but ultimately felt she was out of favor with traditional archaeology. In 1980, her most controversial book, A Quest of Love, in which she imagined herself as a woman over time, left her sidelined by many academics who had never forgiven her for leaving Christopher. Her last publication, with Paul Bahn, was a popular guide to British archaeology. By 1992, when Oxford University launched its own degree in archaeology and anthropology, her best-known books were out of print, and her substantial contribution to archaeology overlooked as it would continue for 20 years. Most recently, A Land, her most acclaimed work, has found a new audience among enthusiasts of nature writing. It was republished in the UK in 2012.

Meanwhile Jacquetta Hawkes's approach to archaeology is becoming known to a generation of contemporary archaeologists who actively seek an engagement with the personal past. I believe she personifies what I have come to term "creative archaeology" in which the processes of excavation, and investigation, are transformed into other artistic practices and forms. She died in Cheltenham on March 18, 1996. Her ashes were interred with JB Priestley's, and her archive is with his in Special Collections at the University of Bradford.

\section{Major Accomplishments}

1. Elected a Fellow of the Society of Antiquaries of London, 1940

2. Archaeology advisor to the Festival of Britain, 1951

3. Governor of the British Film Institute (BFI)

4. Coeditor, UNESCO History of Mankind

5. Cofounder, Campaign for Nuclear Disarmament (CND)

6. Vice-president, Council for British Archaeology

7. OBE, Order of the British Empire medal

\section{Cross-References}

1. Christopher Hawkes

2. Mortimer Wheeler

\section{References}

Hawkes, Jacquetta. 1951. A Land. London: Cresset Press. 
Finn, Christine. 2004. Jacquetta Hawkes. Oxford: New Oxford Dictionary of National Biography, OUP.

Hawkes, Jacquetta. 1968. The proper study of mankind. Antiquity XLII, pp 255-262.

CrossRef

Prehistoric Britain: Christopher and Jacquetta Hawkes. 1943. Pelican Books.

Further Readings include

Collins, Diana. 1994. Time and the Priestleys: the story of a friendship, Stroud: Alan Sutton.

Finn, Christine. 2000. Ways of telling: Jacquetta Hawkes as film-maker. Antiquity 74, pp 127-130.

CrossRef

Macfarlane, Robert. 2012. Introduction to a new edition of A Land. Collins Perennial. 